\title{
Heterologous expression of staphylococcal enterotoxin B (seb) gene for antibody production
}

\section{Dev Vrat Kamboj*}

Biotechnology Division

Defence Research and Development Establishment

Jhansi Road, Gwalior- 474002

India

Tel: 917512233489

Fax: 917512341148

E-mail:kamboj_dev@yahoo.com

\section{Vijay Nema}

Biotechnology Division

Defence Research and Development Establishment

Jhansi Road, Gwalior- 474002

India

Tel: 917512233489

Fax: 917512341148

E-mail: nema_vijay@yahoo.com

\section{Arun Kumar Pandey}

Biotechnology Division

Defence Research and Development Establishment

Jhansi Road, Gwalior- 474002

$$
\text { India }
$$

Tel: 917512233489

Fax: 917512341148

E-mail: arunpanday1@rediffmail.com

\author{
Ajay Kumar Goel \\ Biotechnology Division \\ Defence Research and Development Establishment \\ Jhansi Road, Gwalior- 474002 \\ India \\ Tel: 917512233489 \\ Fax: 917512341148 \\ E-mail: akgoel73@yahoo.co.uk

\section{Lokendra Singh} \\ Biotechnology Division \\ Defence Research and Development Establishment \\ Jhansi Road, Gwalior- 474002 \\ India \\ Tel: 917512233489 \\ Fax: 917512341148 \\ E-mail: 1st2397@rediffmail.com
}

Financial support: This work was supported by the financial assistance obtained from Defence Research and Development Organization, Ministry of Defence, Government of India.

Keywords: affinity purification, biotin fusion, ELISA, gene cloning, SEB, western blot

$\begin{array}{ll}\text { Abbreviations: } & \text { BCA: Bicinchoninic acid } \\ \text { BW: biological warfare } \\ \text { DAB: diaminobenzidine } \\ \text { FCA: Freund's Complete Adjuvant } \\ \text { FIA: Freund's Incomplete Adjuvant } \\ \text { MHC: major histocompatability complex } \\ \text { OD: optical density } \\ \text { OPD: } o \text { - phenylenediamine } \\ \text { SEs: staphylococcal enterotoxins } \\ \text { SFP: staphylococcal food poisoning }\end{array}$

*Corresponding author 
Staphylococcal food poisoning (SFP) is caused by the members of superantigen family called staphylococcal enterotoxins (SEs). About 20 different types of SEs are produced by Staphylococcus aureus out of which type A (SEA), B (SEB), C (SEC) and D (SED) are commonly implicated in SFP. Among these, SEB is the most potent toxin and has also gained the status of biological warfare (BW) agent. Therefore, detection of SEB is of utmost importance. Any immunological detection system for SEB requires specific and sensitive antibodies which inturn depends on the purity of the SEB. In the present investigation, seb gene of $S$. aureus was cloned and expressed in $E$. coli along with biotin as fusion partner to facilitate the purification process. The yield of purified recombinant SEB was $13.1 \mathrm{mg} / \mathrm{L}$ of culture broth. Biotin tag from the biotinylated toxin was removed by protease cleavage, and both biotinylated and non-biotinylated toxin types were used for raising hyperimmune antiserum. Antisera were also specific for SEB amongst different kinds of food poisoning agents tested by indirect plate ELISA and western blot analysis. The quality of the antisera raised in this study was found superior to the commercially available antiserum. The investigation suggests that construction of recombinant staphylococcal enterotoxin $B$ is a good alternative for production of pure enterotoxin to be used in antibody generation.

Staphylococcal food poisoning (SFP), a form of enteritis, is intoxication rather than a disease resulting from ingestion of food contaminated with preformed staphylococcal enterotoxins (Bergdoll et al. 1974). Symptoms of SFP usually occur within 1-6 hrs after the food intake and are characterized by nausea, vomiting, abdominal cramps and diarrhoea. These symptoms usually subside in 1-3 days but the patient remains sick for 7-10 days due to the result of toxic shock (Jett et al. 1994; Do Carmo et al. 2004). Toxic shock causing SEs are single chain polypeptides having a molecular weight ranging from 27-29 kDa. SEs can withstand boiling temperature for several minutes, extremes of $\mathrm{pH}(3-11)$ and protease digestion by gastric enzymes (Soriano et al. 2002). Twenty different types of SEs, viz., SEA through SEE, SEG through SER and SEU have already been discovered, however, only a few of the toxin serotypes are frequently associated with food poisoning outbreaks (Martin et al. 2004; Fernández et al. 2006). Toxin serotypes frequently associated with food poisoning outbreaks are SEA, SEB, SEC and SED (Balaban and Rasooly, 2000; Smyth et al. 2005).

Staphylococcal enterotoxins are 'Superantigens' and are able to bind to the major histocompatability complex (MHC) class II antigen, causing massive T cell stimulation coupled with the release of cytokines. The release of cytokines results in stimulation of neuro-receptors in the intestinal tract, and triggers vomiting center in the brain (Komisar et al. 1994; Kaempfer et al. 2002; Hemalatha et al. 2004). This effect is more severe in case of intoxication involving SEB which is also a listed biological warfare
(BW) agent (Franz et al. 1997; Baker et al. 2002; Pettersson and Forsberg, 2002; Boles et al. 2003). Therefore, it is of utmost importance to develop immunological detection system for SEB, the success of which is dependent on the purity of SEB used for generating anti SEB antibodies.

Conventionally, molecular sieving and ion exchange chromatography have been used either independently or in tandem for purification of Staphylococcal enterotoxins (Tranter and Brehm, 1990; Coffman et al. 2002; Dainiak et al. 2005). Isoelectric focusing has been proved useful for purification of small amounts of staphylococcal enterotoxins but on a preparative scale the procedure has generally been used in combination with ion exchange chromatography and gel filtration (Tranter and Brehm, 1990). Use of these techniques in tandem is tedious, time consuming, expensive and sometimes does not result in purification of staphylococcal enterotoxins to the level of homogeneity. A slight contamination of toxin with other bacterial proteins results in antibodies that are less specific for the enterotoxin and hence have poor detection potential leading to false positive results. Therefore, in the present investigation, the staphylococcal enterotoxin B (seb) gene was cloned and co-expressed with biotin as fusion partner facilitating single step affinity purification. The suitability of the purified recombinant SEB was also studied for raising anti SEB antibodies.

\section{MATERIALS AND METHODS}

\section{Staphylococcal enterotoxin B (seb) gene amplification}

SEB producing $S$. aureus ATCC14458 was used to amplify the toxin gene for cloning and expression. Primers for amplification of $s e b$ gene were designed in our laboratory using the Primer Select 5.07 software of Lasergene version 5.07/5.52 (DNA STAR Inc., USA) and were custom synthesized by M/s Metabion, Germany. The nucleotide sequences of forward and reverse primers were: 5'AGAGAGTCAACCAGATCCTAA-3' (21 NT) and 5'TCACTTTTTCTTTGTCGTAACAT-3' (23 NT), respectively. The optimized PCR conditions were: initial denaturation at $94^{\circ} \mathrm{C}$ for 2 min followed by 25 cycles of denaturation $\left(94^{\circ} \mathrm{C} / 30 \mathrm{sec}\right)$, annealing $\left(52^{\circ} \mathrm{C} / 60 \mathrm{sec}\right)$, extension $\left(72^{\circ} \mathrm{C} / 90 \mathrm{sec}\right)$; and final extension at $72^{\circ} \mathrm{C}$ for 5 min. The $s e b$ amplicon was checked by electrophoresis on agarose $(1.5 \%)$ containing $0.5 \mu \mathrm{g} / \mathrm{ml}$ ethidium bromide and visualized on Gel Documentation System (Bio-Rad, USA).

\section{Ligation and transformation of seb into $E$. coli}

The seb amplicon was purified using Montage Gel Extraction Kit (Millipore, USA) and ligated at $16^{\circ} \mathrm{C}$ for 4 hrs with fusion vector, PinPoint Xa-1 T, containing biotin tag as per manufacturer's instructions (Promega Corp., USA). The ligated product was analysed on agarose gel for its integrity and was transformed into the expression host $E$. coli JM109 following the protocol reported earlier (Devvrat 


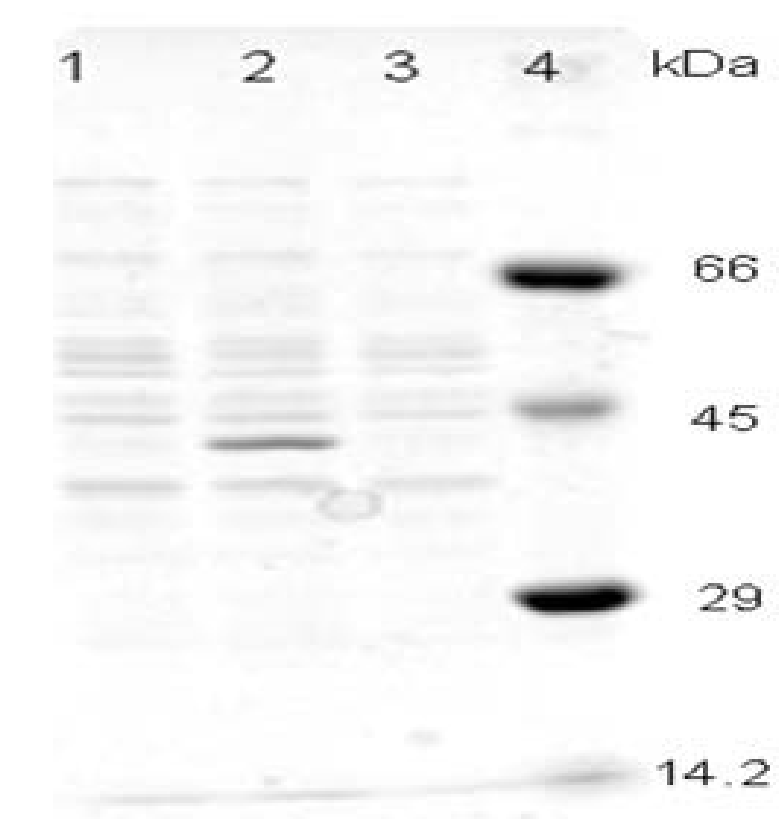

Figure 1. SDS-PAGE profile showing uninduced recombinant clone (lane 1) and induced clone showing $r$ SEB band at 41.4kDa (lane 2), E. coli host JM109 (lane 3) and molecular weight markers (lane 4).

et al. 1994). Transformants were plated on LB agar containing ampicillin $(100 \mu \mathrm{g} / \mathrm{ml})$ for the selection of recombinant clones. PCR was performed to screen the clones for the presence of toxin gene. The toxin gene in the vector was sequenced to check the possible point mutation. The sequencing was carried out by automated capillary sequencer ABI 3100 of Applied Biosystems, USA.

\section{Expression in recombinant clones}

Clones, found positive by PCR for the presence of seb gene, were checked for the expression after IPTG (isopropyl- $\beta$-D-thiogalactopyranoside) induction, lysis and SDS-PAGE (Krishnanchettiar et al. 2003). The presence of enterotoxin protein was confirmed by western blotting (Zhou and Singh, 2004) using both streptavidin alkaline phosphatase (Promega Corp., USA) and antiserum against natural SEB raised earlier in the laboratory.

\section{Optimization of expression conditions for the production of recombinant SEB}

One of the SEB positive recombinant clones, 1SEBR4, was used to standardize the growth and induction conditions for expression of recombinant SEB (r-SEB). Induction point, duration of induction and concentration of inducer, i.e., IPTG were optimized by growing the clone in LB medium containing ampicillin. Briefly, a $100 \mathrm{ml}$ flask containing 20 $\mathrm{ml}$ of LB medium, biotin $(2 \mu \mathrm{M})$ and ampicillin (100 $\mu \mathrm{g} / \mathrm{ml})$ was inoculated with $200 \mu \mathrm{l}$ of overnight grown broth culture obtained from a single colony of 1SEBR4. Different OD values (0.2-0.7) were optimized for the time of adding inducer to the culture followed by induction duration (1-6 hrs). The concentration of inducer (IPTG) was also standardized to obtain maximum yield of recombinant toxin. Cells were harvested by centrifugation at $8000 \mathrm{x}$ g for $10 \mathrm{~min}$ and frozen at $-80^{\circ} \mathrm{C}$ till use.

\section{Recombinant SEB purification}

Recombinant SEB was purified from cell lysate using SoftLink $^{\mathrm{TM}}$ Soft Release Avidin Resin (Promega Corp., USA). Batch mode affinity purification was done as per the manufacturer's instructions and recombinant toxin was digested with Factor Xa-Protease for removal of biotin tag. Conditions for complete digestion of fusion protein were standardized with regard to the time of incubation (4-16 hrs) and concentration of enzyme (2-10\%). Yields were calculated by estimating the total protein and the purified $r$ SEB using Bicinchoninic acid (BCA) method (Koenig et al. 2004). The N-terminal sequencing of the Factor Xa digested r-SEB was carried out to check the N-terminal site of the digested r-SEB by Automated Edman Degradation method using Applied Biosystems 494 Procise Protein Sequencing System. Further peptide sequencing was performed to check the amino acid sequence homology of digested r-SEB with the known natural SEB protein. The sequencing was carried out by electrospray time-of-flight mass spectrometry (LC/MS/TOF) using Q Star Pulsar Applied Biosystems, USA) and spectra were analysed by Mascot Sequence Matching Software (Matrix Science).

\section{Immunization of mice}

Female Balb/c mice $(20-25$ g) were immunized intraperitonially for 60 days at an interval of 15 days. Undigested and enzyme digested r-SEB (500 $\mu \mathrm{l})$ emulsified with Freund's Complete Adjuvant (FCA) in 1:1 ratio were used to prime the mice followed by booster doses with Freund's Incomplete Adjuvant (FIA). Doses of $50 \mathrm{ng}, 1 \mu \mathrm{g}$, $50 \mu \mathrm{g}, 100 \mu \mathrm{g}$ and $150 \mu \mathrm{g}$ were used for immunization.

\section{Evaluation of antibodies raised against r-SEB}

Mice were bled through retro-orbital route after 14 days of final booster, serum was separated and its titre was determined using western blot. The antiserum was also tested for its cross reactivity with SEA, SEC and SED enterotoxins, E. coli JM109 host, non-enterotoxigenic $S$. aureus strain ATCC6538P and other microorganisms that can gain access in the food, viz., Bacillus subitils, Enterococcus faecalis, Bacillus anthracis, Shigella dysenteriae, Salmonella typhi, Clostridium perfringens type A, Clostridium botulinum types $\mathrm{A}$ and $\mathrm{E}$, and Staphylococcus epidermidis by indirect ELISA (Agarwal et al. 2002) and western blot. SEA, SEC, SED and supernatants of overnight grown cultures of test organisms were run on polyacrylamide gel for western blot, and 


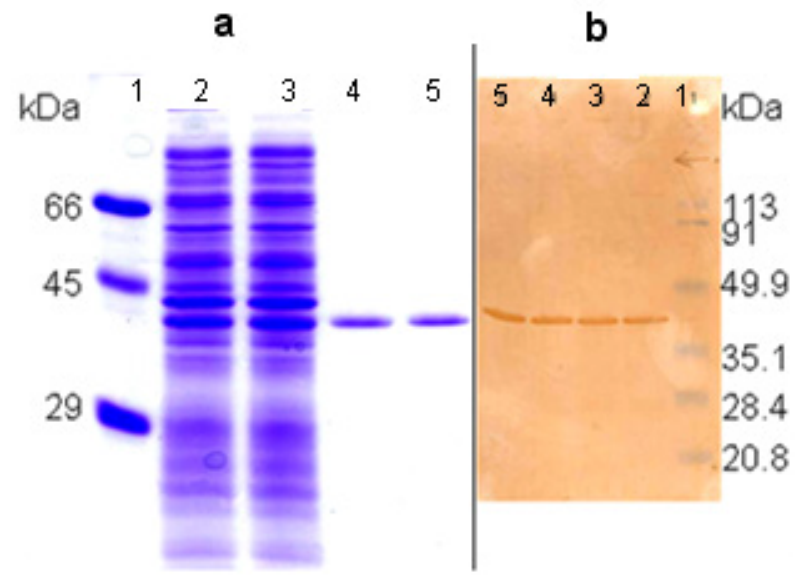

Figure 2. SDS-PAGE and western blot profiles showing affinity purified r-SEB. Panel a shows SDS-PAGE profile of 1SEBR4 cell lysate (lanes 2 and 3), and affinity purified r-SEB (41.4 kDa) (lanes 4 and 5), lane 1 shows molecular weight markers. Panel b shows western blot profile of 1SEBR4 cell lysate showing r-SEB (lanes 2 and 3 ), and affinity purified $r$ SEB bands at $41.4 \mathrm{kDa}$ (lanes 4 and 5), lane 1 shows molecular weight markers.

coated onto the 96 wells polystyrene plate (Nunc, Denmark) for ELISA. Mouse anti r-SEB serum as source of primary antibodies and anti mouse immunoglobulins-HRP conjugate (Dako, Denmark) as revealing antibodies were used at 1:2000 dilutions. The 3, 3'- diaminobenzidine (DAB) for western blot, and the $o$ - phenylenediamine (OPD) for ELISA were used as substrates to develop the reaction colour. The ELISA reaction was read at $492 \mathrm{~nm}$. Performance of anti r-SEB serum was also compared with the commercially available antiserum from $\mathrm{M} / \mathrm{s}$ Toxin Technology, USA. Both the antibodies were tested at 1:2000, 1:5000 and 1:10000 dilutions for specificity against culture supernatants of SEB producing $S$. aureus strain ATCC14458 and non-enterotoxigenic strain ATCC6538P using the western blot test format as described above.

\section{RESULTS AND DISCUSSION}

SEs are the second most common agents of food poisoning all over the world (Balaban and Rasooly, 2000; Greenfield et al. 2002; Di Pinto et al. 2004; Smyth et al. 2005). Among these, SEB is the most potent and a listed BW agent (Baker et al. 2002; Kaempfer et al. 2002; Pettersson and Forsberg, 2002; Boles et al. 2003). Therefore, it is imperative to have an immunological system for detection of SEB. The major problem encountered in the development of an immunological detection system is the limitation of high affinity and specific antibodies against SEB because of its superantigenic nature. Slight contamination of other proteins leads to low affinity and non-specific antibody response against the target super-antigen. Therefore, SEB should be available in highly pure form. Purification of SEB is tedious and time consuming by conventional protein purification methods like size exclusion and ion-exchange chromatography (Tranter and Brehm, 1990; Coffman et al. 2002; Dainiak et al. 2005). An alternative approach to achieve high level of protein purity is heterologous expression of desired gene into a suitable vector containing a fusion partner that can be used as affinity tag for single step purification (Nilsson et al. 1997; Constans, 2002; Mukherjee et al. 2003).

In the present study, seb gene of $S$. aureus ATCC14458 was amplified by PCR that resulted in $721 \mathrm{bp}$ amplicon. The PCR amplified gene was ligated to PinPoint Xa-1 Tvector having biotin as fusion partner. The recombinant vector containing the $s e b$ gene was transformed into $E$. coli JM109. Eight transformants were analysed for the presence of seb gene by PCR and all were found to contain the insert. The orientation of seb gene was determined by sequencing and the gene sequence was found identical with that of $s e b$ gene of $S$. aureus strain ATCC14458 already submitted by the authors to the NCBI GenBank (Accession number AY852244). The gene sequence was also identical with the earlier reported seb genes from $S$. aureus strain S6 and the partial $s e b$ gene sequence from strain ATCC14458 (Jones and Khan, 1986; Sergeev et al. 2004).

Seven out of eight transformants showed inducible expression of fusion protein in JM109. A thick band of rSEB toxin was observed at approximately $41.4 \mathrm{kDa}$ position upon induction of recombinant clones by IPTG (Figure 1). The position of the r-SEB toxin was also confirmed by western blots developed with streptavidinalkaline phosphatase conjugate and rabbit anti SEB antibodies (data not shown) raised earlier in the laboratory against natural SEB toxin (Nema et al. 2004). Among the inducible clones, 1SEBR4 was selected for further studies of gene expression and protein purification. Induction conditions, viz., induction point, induction duration and inducer concentration were optimized for the clone, 1SEBR4. Optimum optical density (OD) for adding the inducer, i.e., IPTG was 0.3-0.4 which was achieved within 2-3 hrs of culture inoculation. The maximum yield of $r-$ SEB was obtained when 1SEBR4 was induced by IPTG at a concentration of $75 \mu \mathrm{M}$ for four hours. Cells from induced clone were sonicated and the cell lysate was used for single step affinity purification of r-SEB by using SoftLink ${ }^{\mathrm{TM}}$ Soft Release Avidin Resin. The purified r-SEB showed single band on SDS-PAGE and western blot developed by rabbit anti SEB antibodies raised earlier in our laboratory (Figure 2). The advantage of using biotin as purification tag was reflected in the purity of the r-SEB as revealed by the presence of single band on SDS-PAGE. On the other hand use of HIS tag, sometimes, results in copurification of non-specific metal binding proteins in addition to heterologously expressed protein (Finzi et al. 2003; Mukherjee et al. 2003). The yield of purified r-SEB was $6.6 \%(\mathrm{w} / \mathrm{w})$ of total protein and $13.1 \mathrm{mg} / \mathrm{L}$ of culture broth. The estimated yield of r-SEB obtained by Ignatov et al. (1993) was $1.7 \%$ only whereas Yang et al. (2002) reported a yield of $33.3 \%$ in JM109. The major limitation of both these investigations was that they did not use 


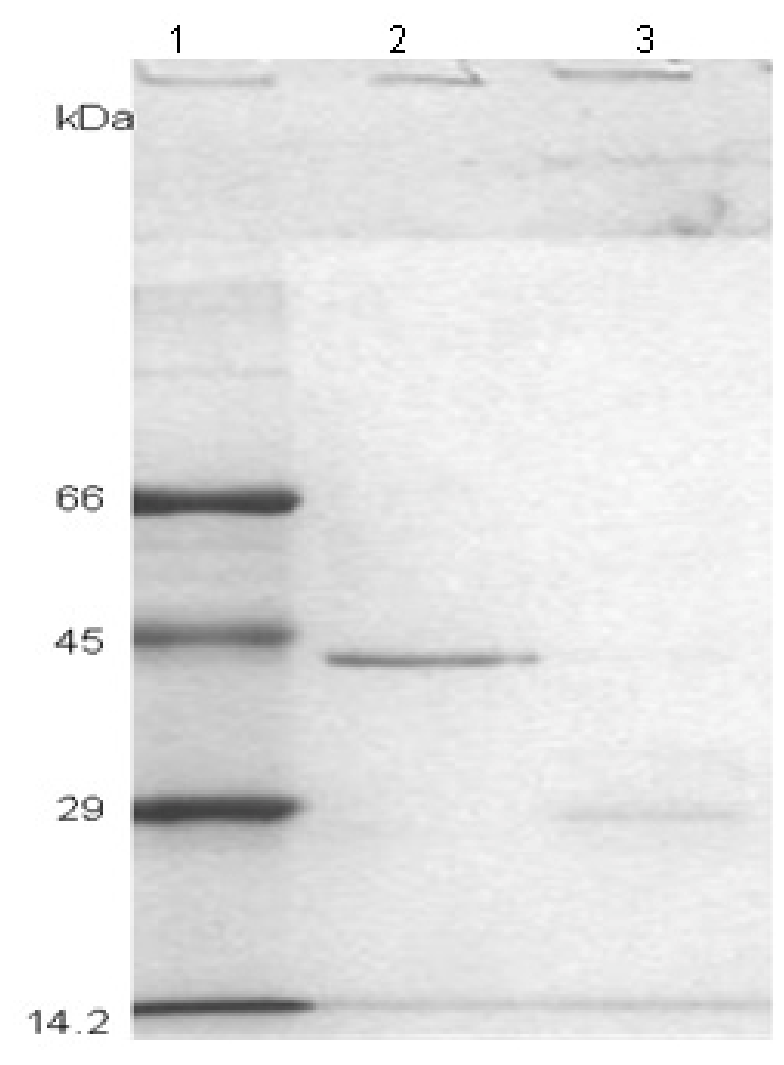

Figure 3. SDS-PAGE profile showing undigested $r$-SEB at $41.4 \mathrm{kDa}$ (lane 2) and Factor Xa digested r-SEB at $29.5 \mathrm{kDa}$ (lane 3). Lane 1 shows molecular weight markers.

affinity tag for purification of the toxin. Moreover, none of these workers indicated the specific applications of r-SEB.

In the present investigation, r-SEB fusion protein was further used for raising the hyper immune serum in mice to study its suitability for detection of SEB. The r-SEB was subjected to Factor Xa protease digestion to remove the biotin affinity tag so that its possible interference with specific and high titre antibody generation against r-SEB can be avoided. Factor Xa protease concentration of $8 \%$ (w/w) was found optimum for complete removal of biotin tag from r-SEB when incubated for 16-18 hrs (Figure 3). The N-terminal sequencing of the protease digested r-SEB confirmed its proper cleavage by Factor $\mathrm{Xa}$ protease. The LC-MS profile of the protease digested r-SEB showed that the amino acid sequence of r-SEB was matching with the natural SEB toxin. Size of the protease digested r-SEB was estimated to be $29.5 \mathrm{kDa}$ by LC-MS. The protease digested r-SEB (29.5 kDa) and undigested r-SEB (41.4 kDa) were used for immunizing mice. Serum titres obtained in both the cases were 1:32000 as revealed by western blot. These sera were further evaluated for their cross reactivity with SEA, SEC and SED enterotoxins, non-enterotoxigenic $S$. aurues strain ATCC6538P, E. coli host JM109, Bacillus

subitils, Enterococcus faecalis, Bacillus anthracis, Shigella dysenteriae, Salmonella typhi, Clostridium perfringens type A, Clostridium botulinum types $\mathrm{A}$ and $\mathrm{E}$, and Staphylococcus epidermidis. No cross reactivity of the sera was observed either with other non-SEB enterotoxins of $S$. aureus or with the tested strains by the test formats used, i.e., western blot and indirect plate ELISA. Staphylococcal enterotoxins and bacterial species used in this investigation for evaluation of the cross reactivity of the anti r-SEB serum are the ones which are either commonly present in the food or are important BW agents. Further, the antiserum raised in this study was found more specific for SEB detection than the other commercial antiserum available from M/s Toxin Technology, USA. During comparative evaluation of sera using western blot technique, commercial antiserum showed multiple non-specific bands even at 1:10000 dilution with culture supernatant of SEB producing $S$. aureus strain ATCC14458 and non-enterotoxigenic $S$. aureus (Figure 4). Both the antibodies were used at 1:2000, 1:5000 and 1:10000 dilutions which are commonly employed for ELISA and western blot analysis. Antiserum raised in the present investigation did not show cross reactivity even at 1:2000 dilution. This demonstrates the superiority of the antiserum raised against purified r-SEB in this study and the importance of toxin purity for polyclonal

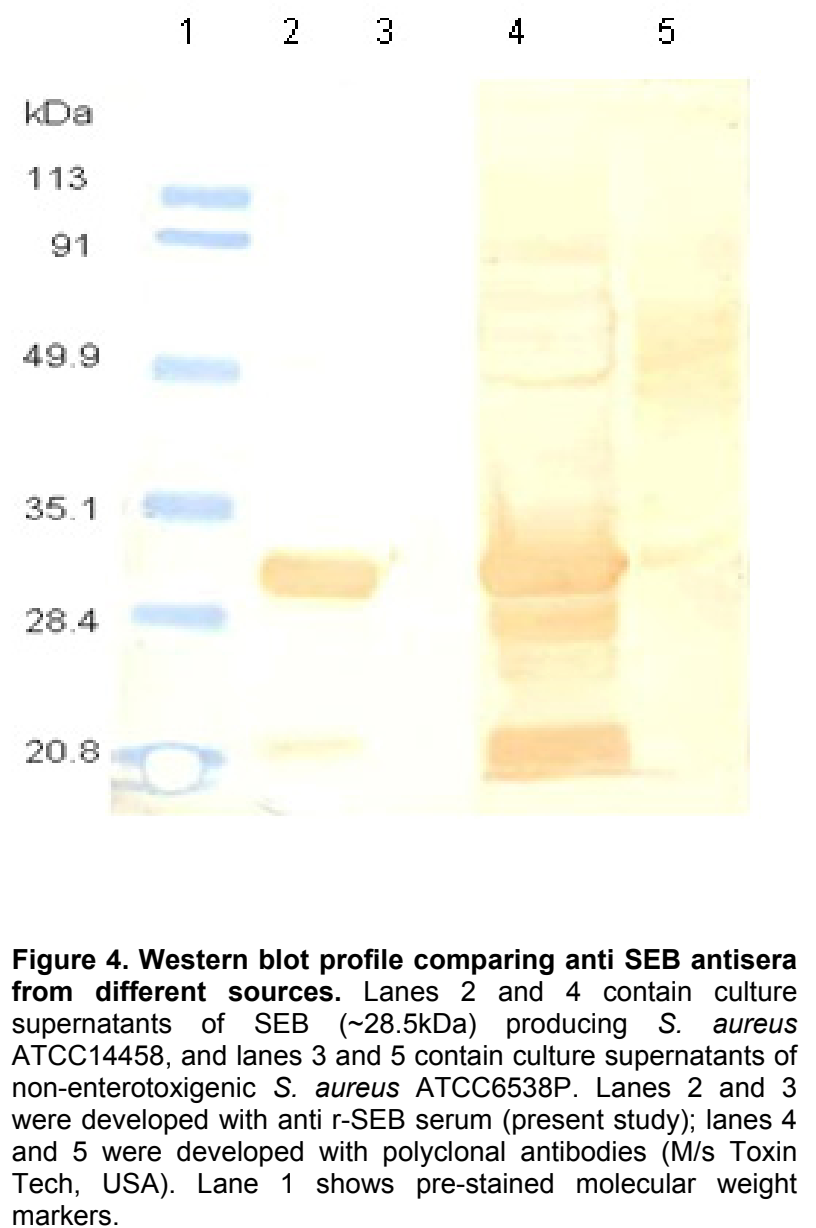


antibody production.

Expression of r-SEB with biotin as fusion partner facilitates the single step affinity purification of r-SEB for generation of specific antibodies against it. Removal of biotin tag from the expressed protein is a costly and time consuming process. In this study, r-SEB without biotin fusion did not show any advantages over r-SEB fused with biotin for raising antiserum in terms of titre and cross-reactivity. Therefore, r-SEB along with biotin tag can be used for polyclonal antibody generation saving a lot of downstream processing time and cost. The anti r-SEB serum developed during the present study is specific and highlights the need of pure SEB toxin for generation of specific polyclonal antibodies. This antiserum can be used in a suitable format for development of an immunological system for detection of SEB. This can also be used for quality control of food products as well as for retrospective detection of SEB in cases of sabotage and/ or covert bioterrorism activities.

AY852244. Enterotoxin B gene (seb) sequence of Staphylococcus aureus strain ATCC14458. NCBI Genbank.

\section{ACKNOWLEDGMENTS}

Authors are thankful to Er. Shri K. Sekhar, Director DRDE Gwalior and Dr. M.C. Varadaraj, Scientist 'E', CFTRI, Mysore for their help and support during the course of this investigation.

\section{REFERENCES}

AGARWAL, G.S.; KAMBOJ, D.V.; ALAM, S.I.; DIXIT, M. and SINGH, L. Environmental detection of Bacillus anthracis spores. Current Science, September 2002, vol. 83, no. 6, p. 697-699.

BAKER, Matthew D.; PAPAGEORGIOU, Anastasssios C.; TITBALL, Richard W.; MILLER, Julie; WHITE, Sarah; LINGARD, Bryan; LEE, Jeong Jin; CAVANAGH, David; KEHOE, Michael A.; ROBINSON, John H. and ACHARYA, K. Ravi. Structural and functional role of threonine 112 in a superantigen Staphylococcus aureus enterotoxin B. Journal of Biological Chemistry, January 2002, vol. 277, no. 4, p. 2756-2762.

BALABAN, Naomi and RASOOLY, Avraham. Staphylococcal enterotoxins. International Journal of Food Microbiology, October 2000, vol. 61, no. 1, p. 1-10.

BERGDOLL, Merlin S.; HUANG, I.Y. and SCHANTZ, Edward J. Chemistry of the staphylococcal enterotoxins. Journal of Agricultural and Food Chemistry, January 1974, vol. 22 , no. 1, p. 9-13.

BOLES, James W.; PITT, M. Louise M.; LECLAIRE, Ross D.; GIBBS, Paul H.; TORRES, Edna; DYAS, Beverly; ULRICH, Robert G. and BAVARI, Sina. Generation of protective immunity by inactivated recombinant staphylococcal enterotoxin $\mathrm{B}$ vaccine in nonhuman primates and identification of correlates of immunity. Clinical Immunology, July 2003, vol. 108, no. 1, p. 51-59.

COFFMAN, J. Daniel; ZHU, Jianwei; ROACH, John M.; BAVARI, Sina; ULRICH, Robert G. and GIARDINA, Steven L. Production and purification of a recombinant staphylococcal enterotoxin B vaccine candidate expressed in Escherichia coli. Protein Expression and Purification, March 2002, vol. 24, no. 2, p. 302-312.

CONSTANS, Aileen. Protein purification I: Liquid chromatography. The Scientist, January 2002, vol. 16, no. 2, p. 40.

DAINIAK, Maria; HEDSTROM, Martin; GALAEV, Igor Y. and MATTIASSON, Bo. Improved methods for prepurification and detection of staphylococcal enterotoxin B from cell-free culture filtrate. Biotechnology Progress, August 2005, vol. 21, no. 4, p. 1347-1351.

DEVVRAT, D; SHARMA, P.K. and KUNDU, B.S. Construction of Rhizobium sp (Cicer) containing lacZ fusions for ecological studies. Annals of Biology, 1994, vol. 10, p. 86-97.

DI PINTO, A.; FORTE, V.T.; CICCARESE, G.; CONVERSANO, M.C. and TANTILLO, G.M. Comparison of reverse passive latex agglutination test and immunoblotting for detection of staphylococcal enterotoxin A and B. Journal of Food Safety, November 2004, vol. 24, no. 4, p. 231-238.

DO CARMO, Luiz Simeäo; CUMMINGS, Christiano; LINARDI, Valter Roberto; DIAS, Ricardo Souza; DE SOUZA, Josélia Maria; DE SENA, Maria José; DOS SANTOS, Deise Aparecida; SHUPP, Jeffrey W.; PERES PEREIRA, Renata Karla and JETT, Marti. A case study of a massive staphylococcal food poisoning incident. Food Borne Pathogens and Disease, December 2004, vol. 1, no. 4, p. 241-246.

FERNÁNDEZ, Marisa M.; DE MARZI, Mauricio C.; BERGUER, Paula; BURZYN, Dalia; LANGLEY, Ries J.; PIAZZON, Isabel; MARIUZZA, Roy A. and MALCHIODI, Emilio L. Binding of natural variants of staphylococcal superantigens SEG and SEI to TCR and MHC class II molecule. Molecular Immunology, March 2006, vol. 43, no. 7, p. 927-938.

FINZI, Andrés; CLOUTIER, Jonathan and COHEN, Éric A. Two-step purification of His-tagged Nef protein in native condition using heparin and immobilized metal ion affinity chromatography. Journal of Virological Methods, July 2003, vol. 111, no. 1, p. 69-73.

FRANZ, D.R.; JAHRLING, P.B.; FRIEDLANDER, A.M.; MCCLAIN, D.J.; HOOVER, D.L.; BRYNE, W.R.; PAVLIN, J.A.; CHRISTOPHER, G.W. and EITZEN JR., E.M. Clinical recognition and management of patients 
exposed to biological warfare agents. The Journal of the American Medical Association, August 1997, vol. 278, no. 5, p. 399-411.

GREENFIELD, Ronald A.; BROWN, Brent R.; HUTCHINS, James B.; IANDOLO, John J.; JACKSON, Rhett; SLATER, Leonard N. and BRONZE, Michael S. Microbiological, biological, and chemical weapons of warfare and terrorism. The American Journal of the Medical Science, June 2002, vol. 323, no. 6, p. 326-340.

HEMALATHA, V.; SRIKANTH, P. and MALLIKA, M. Superantigens- Concepts, clinical disease and therapy. Indian Journal of Medical Microbiology, OctoberDecember 2004, vol. 22, no. 4, p. 204-211.

IGNATOV, K.B.; CHISTIAKOVA, L.G.; SHEMCHUKOVA, O.B.; GORODETSKAIA, S.B. and KISELEV, V.I. Cloning of Staphylococcus aureus enterotoxin B gene, obtained by polymerase chain reaction, and its expression in Escherichia coli cells. Bioorganicheskaia Khimiia, 1993, vol. 19, no. 1, p. 75-80.

JETT, M.; NEILL, R.; WELCH, C.; BOYLE, T.; BERNTON, E.; HOOVER, D.; LOWELL, G.; HUNT, R.E.; CHATTERJEE, S. and GEMSKI, P. Identification of staphylococcal enterotoxin B sequences important for induction of lymphocyte proliferation by using synthetic peptide fragments of toxin. Infection and Immunity, August 1994, vol. 62, no. 8, p. 3408-3415.

JONES, C.L. and KHAN, S.A. Nucleotide sequence of enterotoxin B gene from staphylococcus aureus. Journal of Bacteriology, April 1986, vol. 166, no. 1, p. 29-33.

KAEMPFER, Raymonf; ARAD, Gila; LEVY, Revital and HILLMAN, Dalia. Defence against biologic warfare with superantigen toxins. The Israel Medical Association Journal, July 2002, vol. 4, no. 7, p. 520-523.

KOENIG, Robbin L.; RAY, Jessica L.; MALEKI, Soheila J.; SMELTZER, Mark S. and HURLBURT, Barry K. Staphylococcus aureus AgrA binding to the RNAIII-agr regulatory region. Journal of Bacteriology, November 2004, vol. 186, no. 22, p. 7549-7555.

KOMISAR, J.L.; SMALL-HARRIS, S. and TSENG, J. Localization of binding sites of staphylococcal enterotoxin B (SEB), a superantigen for HLA-DR, by inhibition with synthetic peptides of SEB. Infection and Immunity, November 1994, vol. 62, no. 11, p. 4775-4780.

KRISHNANCHETTIAR, Sangeeth; SEN, Jayita and CAFFREY, Michael. Expression and purification of the Bacillus anthracis protective antigen domain 4. Protein Expression and Purification, February 2003, vol. 27, no. 2, p. 325-330.

MARTIN, M.C.; FUEYO, J.M.; GONZALEZ-HEVIA, M.A. and MENDOZA, M.C. Genetic procedures for identification of enterotoxigenic strains of Staphylococcus aureus from three food poisoning outbreaks. International Journal of Food Microbiology, August 2004, vol. 94, no. 3, p. 279-286.

MUKHERJEE, Sourav; SHUKLA, Anshuman and GUPTASARMA, Purnananda. Single-step purification of a protein-folding catalyst, the SlyD peptidyl propyl isomerase (PPI), from cytoplasmic extracts of Escherichia coli. Biotechnology and Applied Biochemistry, April 2003, vol. 37, no. 2, p. 183-186.

NEMA, V.; KAMBOJ, D.V.; GOEL, A.K. and SINGH, L. Staphylococcal Enterotoxin B: A Comparative Evaluation of Purification Techniques. In: Microtech- 2K4. Annual Conference of the Association of the Microbiologists of India (AMI). $\left(45^{\text {th }}, 23^{\text {rd }}-25^{\text {th }}\right.$ November, 2004, National Dairy Research Institute (NDRI), Karnal, India). Abstracts, 2004. p. 80.

NILSSON, Joakim; STAHL, Stefan; LUNDEBERG, Joakim; UHLEN, Mathias and NYGREN, Per-Áke. Affinity fusion strategies for detection, purification, and immobilization of recombinant proteins. Protein Expression and Purification, October 1997, vol. 11, no. 1, p. $1-16$.

PETTERSSON, H. and FORSBERG, G. Staphylococcal enterotoxin $\mathrm{H}$ contrasts closely related enterotoxins in species reactivity. Immunology, May 2002, vol. 106, no. 1, p. 71-79.

SERGEEV, Nikolay; VOLOKHOV, Dmitriy; CHIZHIKOV, Vladimir and RASOOLY, Avraham. Simultaneous analysis of multiple staphylococcal enterotoxin genes by an oligonucleotide microarray assay. Journal of Clinical Microbiology, May 2004, vol. 42, no. 5, p. 2134-2143.

SMYTH, Davida S.; HARTIGAN, Patrick J.; MEANEY, William J.; FITZGERALD, J. Ross; DEOBALD, Claudia F.; BOHACH, Gregory A. and SMYTH, Cyril J. Superantigen genes encoded by the egc cluster and SaPIbov are predominant among Staphylococcus aureus isolates from cows, goats, sheep, rabbits and poultry. Journal of Medical Microbiology, April 2005, vol. 54, no. 4, p. 401411.

SORIANO, José Miguel; FONT, Guillermina; MOLTO, Juan Carlos and MAÑES, Jordi. Enterotoxigenic staphylococci and their toxins in restaurant foods. Trends in Food Science and Technology, February 2002, vol. 13, no. 2, p. 60-67.

TRANTER, H.S. and BREHM, R.D. Production, purification and identification of the staphylococcal enterotoxins. Society for Applied Bacteriology Symposium Series, 1990, vol. 19, p. 109S-122S. 
Kamboj, D.V. et al.

YANG, L.Q.; WU, W.F.; SHI, C.B.; LU, A.G.; FENG, J.X. and BAI, X.L. Cloning of staphylococcal enterotoxin B gene and its highly expression in Escherichia coli. Chinese Journal of Biotechnology, September 2002, vol. 18, no. 5, p. 597-600.

ZHOU, Yu and SINGH, Bal Ram. Cloning, high-level expression, single-step purification, and binding activity of His $_{6}$-tagged recombinant type $\mathrm{B}$ botulinum neurotoxin heavy chain transmembrane and binding domain. Protein Expression and Purification, March 2004, vol. 34, no. 1, p. 8-16. 